\title{
A Group of Eleventh Graders' Life Stories: Reconstructing Social Identity ${ }^{1}$
}

\section{Las historias de vida de un grupo de alumnos de undécimo grado: Re-construyendo identidad social}

\author{
Josefina Peñaloza Villamizar ${ }^{2}$ \\ Colegio Integrado del Carare \\ josefina1128@hotmail.com
}

Received: March 8, 2016

Accepted: June 9, 2016

How to cite this article (APA, $\mathbf{6}^{\text {th }}$ ed.): Peñaloza, J.(2016). A Group of Eleventh Graders' Life Stories: Reconstructing Social Identity. Enletawa Journal, 9 (2), 15-33

\begin{abstract}
This qualitative and interpretive study aimed to analyze how a group of eleventh graders reconstructed their social identity through life stories and writing related tasks in their native language. This notion is supported in professional literature: "Constructing and reconstructing identity through narratives is like giving sense to the life," "It is like reorganizing the story lived," (Park \& Burgess, 1924, p. 4). "It is like trying to assume what has happened with the lives and turn them into stories," (Hardy, 1968, p. 9). The Reconstruction of identity can be expressed through language learning in the way students use narratives; such narratives can provide a glimpse into students' private world, (Pavlenko, 2007). The instruments from which data was collected were life stories and interviews. The four participants reconstructed their identity with descriptions of overcoming abuse and mistreatment, fighting to survive and to continue ahead, and creating a better life.
\end{abstract}

1 Research report.

2 Is a language teacher in a public school in Cimitarra, Santander. She is also a candidate of the M.A. Program in Foreign Language Teaching at Universidad Pedagógica y Tecnológica de Colombia (UPTC). 
Key words: Life stories, Identity, Reconstruction, Social identity, Narratives.

\section{Resumen}

Este estudio cualitativo e interpretativo tuvo como objetivo analizar cómo un grupo de estudiantes del grado undécimo re-construyeron su identidad social a través de narraciones de historias de vida y escribiendo tareas relacionadas, en su lengua materna. Esta noción está apoyada en la literatura profesional: "Construir y reconstruir la identidad a través de narrativas es como dar sentido a la vida"; "Es como reorganizar la historia vivida", (Park \& Burgess, 1924, p.4). "Es como tratar de asumir lo que ha sucedido con las vidas y convertirlas en historias", (Hardy, 1968, p. 9). La Reconstrucción de la identidad se puede expresar a través del aprendizaje de idiomas en la forma en que los estudiantes usan las narrativas; tales narrativas pueden dar una idea del mundo privado de los estudiantes (Pavlenko, 2007). Los instrumentos de los que se obtuvieron datos fueron historias de vida y entrevistas. Los cuatro participantes reconstruyeron su identidad con descripciones de cómo superar el abuso y el maltrato, luchando para sobrevivir y continuar, y crear una vida mejor.

Palabras clave: Historias de vida, Identidad, Re-construcción, Identidad social, Narrativas. 


\section{Introduction}

Teachers sometimes struggle trying to cope with many types of identities, characters, and behaviors on the part of their students, but occasionally these identities bring trouble into the school and the classroom because teachers and students, at times, have difficulty accepting mutual differences. Teachers regularly try to influence students to follow a type of behavior model accepted by society, yet students often try to behave and imitate what mass media displays constantly as models to follow. Recognition of this situation provided the impetus to explore and try to understand how a group of eleventh graders can use storytelling to reconstruct their social identity, even in a violent social context, while trying to fit in a group.

Students construct and reconstruct identity to a degree at school every day. As stated by Connelly \& Clandinin (1999), school has enormous implications for young people's sense of identity as members of society, of their families, and of their ethnic communities. Children reconstruct identity when they try to cope with the diverse social contexts in which they live. Tudor (2001) asserts that students' identities are in part the result of factors of a purely individual nature, but students are also influenced by aspects of the context in which they live and study.

Wenger (2000) argues that students display different types of identities in the diverse social contexts in which they live. Similarly, Pavlenko and Blackledge (2004) explain that students learn to construct and reconstruct their identity according to the characteristics of the social contexts and with the groups they interact. For example, when students are with their friends, they are normally happy: they smile, talk, play, and enjoy themselves. When students are in the classroom but not with their friends, they often exhibit timider behavior, frequently afraid of participating in the activities. Levinson (1978) reports that students need to feel accepted. They want to catch the others' attention, and they try to look interesting or attractive to that end. Thorborrow (2005) argues that as students move from place to place, they strive to adapt to the diverse social groups which they have to face, and they adjust the ways of being fit in each one. Students also have life stories to tell according to the life experiences they lived.

The aspects mentioned above prompted this study on the recons-truction of a group of eleventh graders' social identity through producing narratives of life stories and related writing tasks in their native language. As a researcher, I selected a group of eleventh graders' life stories, to conduct this study. Those students volunteered to contribute with the interviews in Spanish (their native language). Therefore, the majority of participants' life story content was in their native language.

The pedagogical implementation was developed with tenth and eleventh graders. 
During the year this study was conducted, students wrote narratives of life stories in their mother tongue. These were analyzed to understand how participants reconstructed their social identities. As a way to engage students and participants within the Foreign Language Learning Process (FLLP), they translated their life stories into English. Students used both languages, Spanish and English, to write their life stories, experiences, and reflections.

Therefore, it is essential to mention the fact that the output of the writing process in the foreign language did not constitute the primary input source for this research project. The English class was the setting in which the students wrote their life stories and where the study was conducted. The participants volunteered to share their interviews which permitted to go deeper in the understanding of the life stories, but they were not translated into English by the participants.

Authors such as McAdams (1985), Denzin (1989), Riessman (1993), Bruner (1987) and Squire (2008) have highlighted the importance of stories and narratives in the construction of identities. That is to say, we interpret and reflect on the way we face the world according to the internal stories we create based on our life experience.

\section{Justification}

All of us human beings construct and reconstruct our identities each instant of our lives as we move through different social groups, (Thorborrow,
2005; Robinson, 2007; Belk, 1988). Snow \& Anderson, 1987; Tajfel, 1978; Norton, 2010 consider that identities are socially constructed, that they are dynamic, that they evolve and adapt to different situations, time, space, and occasions. Deng (1995) adds that as members of a society, people follow certain models, according to the characteristics of countries, regions, cities, towns, and regional cultures in order to fit into the context in which they live, thereby pragmatically reconstructing their identities, in a sense.

Additionally, Wenger (2000) argues that as individuals, in our daily lives, we participate in several social practices or in several communities of practice such as family, school, clubs, church, etc., and we display multiple identities in each one. Dowling (2011) states that constructing identity literally involves life experiences, relationships and connections; he also explains that most of the time we hide part of our identity, yet at other times we loudly project it. For example, when we want to hide our failings, we try to display one kind of identity, a false one, in order to be accepted by social groups. Conversely, we may overtly portray another identity based on our self-perceived more positive qualities. We display a different identity at different times in order to be noticed and accepted, (Dowling, 2011).

It has been pointed out that people use narratives as a way to reconstruct identities, that people, through narra- 
tives, give meaning to their lives, (Bruner, 1987, 1991; Ricœur, 1991a; Taylor, 1989; Polkinghorne, 2007; Squire, 2008). These authors affirm that through constructing stories, we organize and give meaning to our experiences and engage in a type self-construction, that is, we reflect on and interpret our life experience through the construction of life story narratives, which in turn shape who we are.

The use of written life story narratives along with oral interviews in the native language allowed the researcher the possibility to be closer to the students and participants and to know more about their lifestyles and life stories, which in turn provided data to answer the research question: What did a group of eleventh graders' life stories reveal about the reconstruction of their social identities through writing related tasks?

\section{Statement of the Problem}

The violent social context in which I work was the starting point and an essential concern which called my attention to conduct this research in the first place. The public school where this study took place is located in Cimitarra, Santander. Many of the students of this public school have suffered the consequences of violence. For more than 35 years, this region has had problems especially due to paramilitary groups which have sown the seed of crime, death, fear, extortions, displacements, and forced or paid recruitments. Illegal cultivation, prostitution, and drug addiction have a prominent effect on the region.

People from this town have arrived predominantly from different regions of the country such as Antioquia, Chocó, Nariño, Boyacá, the Caribbean region and the plains, often running away from violence. Those different types of culture, behaviors, customs, ideologies, thoughts, feelings, religious beliefs, and identities, produced that students struggled, trying to fit in the new sociocultural context in which they live.

As a teacher at this school for more than 20 years, I have witnessed those divergent situations. The effects of violence were deeply ingrained in the townspeople and were evidenced in parents' and students' behaviors and attitudes. While working with students, I noticed that they were always shifting from one type of identity expression to another. It depended on the social group where they interacted, because they wanted to fit in each one. I constantly observed that, when they were with their friends, they were often happy and active, but when they were in larger peer groups, they were frequently timid or even aggressive.

Those students also often tried to impress the others; they spoke in an effort to appear intelligent or brave, and in front of a group exhibited a degree of shyness. They were trying to assume an identity type in order to fit in a group because they otherwise did not have a 
strong sense of independent identity. Furthermore, students came from different socio-cultural backgrounds and from different places. They had to adapt to the new school group, new peers, new teachers, they had to start another life, which meant having to construct a new identity and being without the friends or boyfriends/girlfriends they had before. Predictably, students faced troubles while adapting to their new life.

\section{Literature Review}

\section{Identity.}

Among the definitions of identity, I decided to choose the following excerpt because it accurately describes what the participants of the study revealed about the reconstruction of their social identity: "Identity is people's concepts of who we are, of what sort of people we are, and how we relate to others" (Hogg \& Abrams, 1988, p. 2). This concept expresses an understanding the particularities of the relationships of the four participants of the study along with the diverse social contexts in which they lived.

Norton's (2000) concept is relevant for the study, because, she views identity as a person's understanding of his/her relationship to the world, how this relationship is constructed in time and space, and how the person understands possibilities for the future. This concept matches what the students told about their life stories, their relation with the world they lived, and specially, how they reflected about the need to overcome the past and the way they looked to improve their possibilities for having a better future.

\section{Social Identity.}

Social identity is a form to describe the way individuals and groups define themselves and are defined by others on the basis of race, ethnicity, religion, language, and culture. Identity is attributed or imputed in an attempt to place or situate people as social objects to others; identity emerges from the context of intergroup relations; they change across time, space, and are reproduced in social interaction, (Snow \& Anderson, 1987; Tajfel, 1978; Norton, 2010). These concepts fit with what the students had to face in diverse places, times and situations to reconstruct their social identities. The four participants of the study lived and were vulnerable in diverse social contexts. Even though, they fought to continue ahead with a life. They also thought about projecting and building a better future to have a happy life.

\section{Reconstruction of identity.}

Robinson (2007) stresses that the process of identity reconstruction essentially involves a subtle balancing act of deep rooted ethnic values, cultures, and modes of operating. He adds that, the reconstruction of identity starts with separation from some role relationship, or other key component of the extended 
self. Belk (1988), states that, the reconstruction of identity begins, when the relative stability of such states is upset by changes in the environment or from within an individual.

The participants had to move from place to place, they felt that they did not belong to a specific social context. Even they considered that they did not have a solid family. The lack of a family made them vulnerable to abuse, hits, abandon, and lack of love. As a consequence of living in such conditions they became rebellious, and two of them were trapped by drugs and alcohol. One girl drank alcohol since she was just ten years old. Nevertheless, all the participants fought to overcome those experiences. Therefore, through reflections and making decisions to have a better future and a happy life they reconstructed their identities.

\section{Life stories.}

McAdams (1993) affirms that identity itself takes form of a story. That life stories are based on biographical facts, (McAdams \& Brown, 2001) and that life stories differ from each other with respect to their structural complexity, that is to say that each participant sees, feels, and tells the life story according to her/his own experience and perception of the reality. People's life stories also have a specific time, place, friends, family and society. Every student had life stories to tell. Being vulnerable to abuse and mistreat gave them life stories to tell, too. They recons- tructed their social identities through narratives of life stories. While they told their stories, they engaged in a type of self-construction. They organized the life stories to reflect their lives, in time, space, plot, characters, etc.

\section{Writing skill.}

Cumming (2006) explains that writing in a foreign language engages a spectrum of mental processes, usually in distinct socio-cultural contexts. Accordingly, the participants developed their ability to write and were motivated to tell their life stories as a result of their experiences within specific cultures. Because the participants and students lived in violent contexts and were vulnerable to abuse, mistreatment, abandonment, violence, and general insecurity, they had no shortage of life stories to write about. They wrote about their socio-cultural contexts and developed the ability to write in the native language and to translate the stories into the foreign language.

\section{Research Design}

The study was structured upon the qualitative paradigm. According to Johnson \& Christensen (2010), this type of study reflects the type of data we collected because it observes behavior in natural environments and takes into account the context in which such behavior occurs. It is also subjective in that it is personally and socially constructed. It searches for patterns, 
themes and holistic features and offers multiple perspectives.

The research approach was interpretive. Interpretations were used to understand and unveil what was behind students' life experiences and life stories, which permitted an understanding of the reconstruction of their social identity.

\section{Setting and Participants.}

The public school where this study took place is located in Cimitarra, Santander, in the heart of Magdalena Medio. The participants of this study were four female students between seventeen and eighteen years old. They reported being vulnerable to abuse, violence, abandonment, rejection, death, and lack of a family. The study was conducted based on these four participants' specific characteristics to understand their life stories and to analyze how they reconstructed their social identity through narratives of life stories.

Life stories were also written to later engage students with the FLLP. As mentioned previously, the output of the writing process in foreign language was not the primary target of inquiry for this particular research project. The four participants were selected taking into consideration qualitative purposeful sampling.

\section{Data Collection Instruments.}

McAdams (1996) has argued that throughout their entire lives, people construct the past, dream the future, and internalize the reality of the present through in a largely narrative way, thus bringing the memory of past experiences into a seemingly present context. To that end, the type of data collected in this research was in the form of life stories, the subsequent analysis of which focused on experiences, feelings, reflections, and life stories.

\section{Life Stories.}

Life stories were used to collect data, because through them students told their life experiences. They told their life stories in written and oral forms.

\section{Unstructured Interviews.}

Interviews were used as a means of going deeper into the students' life stories; it was through this mechanism that the data was confirmed. According to Altheide "we have interviews among the broad range of concerns that enter our lives and help shape our stories" (2002, p.28). To access that broad range, we constructed type of interview that was non-directed and flexible. There was no need to follow a detailed interview guide; rather, the participants of this study had the opportunity to tell their life stories freely. They simply remembered past experiences and told me about them. From time to time, as the researcher, I asked them to clarify 
some ideas or experiences they had recounted.

\section{Instructional Design.}

To enhance students' writing's skills in the foreign language, related writing tasks were planned and assigned throughout the year this study took place. Life stories were collected via these tasks. Students were further exposed to foreign language input through a variety of readings. The readings had specific content which permitted students to learn some expressions, vocabulary, verbs, grammar, etc. After reading the texts and working through comprehension issues, students wrote a short own text of their own in Spanish and then translated it into English. For example, students read about a student's prayer and then wrote a small prayer of their own. Later, they read about someone's birthday' party, and then wrote about their own birthday party. Similarly, they read an article about food and then wrote about one experience when they had cooked for a special occasion.

In so doing, students started to write short stories which, by the end of the same year, expanded to writing their own life stories (see student samples in Appendices $3 \mathcal{E} 4$ ). Students used their native language first because remembering and organizing the life story by time, place, and events was not easy for them to do directly in the foreign language as they had only begun to write in English.
While students learnt to write their life stories, they learnt to use the foreign language, in an interesting manner. The later English language experience was meaningful because they were immersed within their own life stories. They wrote about what they loved or hated. They wrote about their favorite sport or activity, about their birthday party, and about their friends and family.

Having an L2 text model proved valuable in helping them to learn vocabulary related to the issue they wrote each time; for example, when they wrote about their education plans, they had already read about someone else's education plan and could use the content and flow of ideas as a model. After reading each text enough times to understand it, looking up the new words or expressions, they wrote about their own plans. Moreover, they were able to practice the use of sequence markers and common discourse patterns such as, "When I finish my ...I would like to..., or, I'm going to study... because I want to become..."

\section{Data Analysis}

Purposeful sampling (Creswell, 2012, p. 206) in qualitative research means the researcher selects people or sites that permit him/her to understand the central issue or phenomenon at hand (Patton, 1990). Therefore, after observing some student's attitudes and behaviors within the class and reading their life stories, fifteen of them 
were selected as potential participants. Students were asked to volunteer to participate in the study prompting four students to volunteer to share their interviews. To comply with ethics regulations, the study included consent forms from school and parents (see Appendices $1 \mathcal{E} 2$ ).

\section{Methods of Analyzing Data.}

In order to perform an analysis of the narrative content, I took into consideration for not only what was said (form) but also how it was said (manner) and what clues that gave about context and meaning. After reading the students' life stories written in the native language along with transcripts of the interviews, the data was coded, selected and organized in two main categories. The first category was reflections about accepting the need to overcome the past to start to enjoy life, and the second contained reflections primarily about beginning to build a better future.

\section{Findings}

Levinson states that the reconstruction of identity starts, "when the relative stability of such states is upset by changes in the environment or from within an individual" prompted by events such as the death of a relative, an accident, or an illness (1978, p.4). The relative stability of the participants of this study had been upset by the vulnerability they were exposed to.
In the first aforementioned category containing reflections primarily about accepting the need to overcome the past to start to enjoy life, the participants narrated and revealed the way they reconstructed their identities through diverse types of abuse, mistreatment, violence, abandonment, rejection, bullying, and death. For example, Participant 1 wrote in her life story: ${ }^{3}$

"I never lived with my parents, they left me with my grandparents and I never had a desirable childhood for a child ... in my childhood there were outsiders who damaged me as, being raped by a woman during 3 years, until I was nine years old, and I never told my family for fear to be judged."

There were reports of selfdestructive behavior such as drug use or self-mutilation that constituted a reaction to or means of escape from the abuse. Participant 1 illustrated that point in her interview: ${ }^{2}$

"I had become a very lonely girl and, and then I began to blame my mother, I hated her, I began to think that it was her fault,... for leaving me alone, for not having taught me to defend myself in such a small age ... I started then to take bad paths,... to ... to drink; When I was just 10 years old I started smoking, ..."

3 This part of the life story was translated by the researcher.

2 The interviews were done in the mother tongue and translated into English by the researcher. 
After being abused, the participants essentially assumed a new identity in that they became rebellious, they drank alcohol, they tried drugs, etc., which had not been their pattern of behavior before suffering the abuse. They displayed that new identity in their social context in which they lived and interacted. Later, when the participants made decisions to look for specialized help to overcome the past, they assumed a yet new type of identity.

In the second category, reflections about staring to build a better future, many subtopics were identified which showed how the participants of this study had adjusted or reconstructed their social identities. We observed themes such as feeling stronger and resilient, conceptualizing a better future, planning the future, valuing study, looking for a profession to ensure economic independence, and cultivating love and happiness.

Participant 2, for instance, wrote in her life story:

"And my goal is to finish studying and do my career ...nursery chief. And I am going to work. But I do think to study. I am going to study head of nursing, but first I will work to support me."

Participant 1, for example, envisioned her future when she wrote in her life story:

"Well, now I have set myself to overcome myself by showing me that 'I am capable' and that no one will help me if I do not do it. I want to be a professional and depend on myself, to help to my brother and cousins, and my whole family ..."

These and other comments revealed the participants' desire to overcome the past and to fight to have a better life and to look for happiness. After being vulnerable to abuse, the participants expressed a desire to change and crea-te a better future for themselves and their families. This was poignantly highlighted by Participant 1 in her life story:

"I told my family what happened when I was a little girl and I felt that I was free, that I could already smile and live without fear and tell what happened to me ... now my goals are to study English, to be able to work ... for later it is to help to my cousins and brothers with their studies ... Well, now I have proposed to surpass myself, to prove to myself that 'I am able' and that no one will help me if I do not do it, I want to be a professional and to depend on myself, to help my brother and cousins, and my whole family ..."

Neimeyer (2000) asserts that narrative is as a metaphor for reconstructing the self, both in psychotherapy and in research. Therefore, writing the life stories can facilitate the participants being free from bad memories and/or to see surviving the bad experiences as strengths to propel them ahead. In this sense, Participant 3 said in her interview:

"Then it was where I had to go from being that spoiled girl ... that spoiled girl who had what she wanted, who could talk as she 
wanted and say what she wanted and was obeyed ... to become a mature, responsible, person and as create as a shield forme."

Participant 3 was a dominant girl who had copied her stepfather's behavior. He had the power to treat people as he wanted because he had the power of guns. She said in her interview:

"My life is immersed in ... in something ... that is called self-defense, because my dad was a commander of them."

Such a model prompted this participant to behave in a similar manner. She was able to point this out in her interview by describing herself as:

"That spoiled little girl who had everything, who could talk as she wanted, and say what she wanted, and was obeyed."

She identified herself as a tough girl, and everyone obeyed her because her stepfather had the power of guns and everyone obeys a person with that kind of power. But when her stepfather was killed she lost that power, and as she was able to reflect insightfully in her interview:

"And that is where people take advantage. Because they said: she is alone. Then, they bullied me ... then they kick me the chair and told me: Do you see? You are there, in the last row, you are down."

Here she was reconstructing her identity as:
"I had to be mature, I had to be ... a hard person, so to speak, because life like that had put it me ..."

Later, the same Participant 3 expressed the desire to overcome the past and to continue ahead, demonstrating a potentially positive reconstruction of identity:

\begin{abstract}
"If hard things happen to you, it is, because my God decides that you are capable of facing it, because you have to continue ahead. You cannot stay there. That was what helped me, I think, even more so ... to forge me as the person I am ... For me, 'you must always overcome the situations you live."
\end{abstract}

An additional observation worth noting is in regards to the participants' use of first and foreign languages to communicate their life stories; over time, they used their own words and expressions. They expressed their ideas more completely; giving relevance to the facts that meant more for them, selecting the words which best expressed their feelings. They gave more emphasis to some words than to others. For example, Participant 1 said in her interview:

"It is as, when every hurt is leaving you a
scar, a scar, a scar and you are never the
same again"

A similar sentiment was expressed by Participant 3 in her interview: 
"To become a mature, responsible person and how to create as a shield for me .... And here is where I say: I know where I am going to, and I know what I want, because his death made me a mature and responsible person."

The participants selected those particular words and expressions because they communicated deep feelings resulting from their experience. Neimeyer (2000) argued that the self is deeply penetrated by the vocabularies of our place and time and by dominant modes of discourse. Participants were exposed to these vocabularies and discourse modes in the readings, and through those words and expressions, they were able to describe the reconstruction of their social identity.

\section{Implications for further Practice}

The process of identity reconstruction through narratives of life stories was meaningful as a research practice. Students benefitted from it not only in terms of reconstructing their social identity but also in terms of writing skill development. The FLLP became meaningful because students communicated their feelings, experiences, reflections, and life stories. It also helped unveil how students face the world and consider their futures.

Moreover, it prompted teachers to reflect on their own practices and to make changes based on a new awareness of the complexity of their student populations.

\section{Conclusions}

Students had hard life stories to tell; they were human beings that needed to be heard. To express themselves in this setting, they used the words and expressions that they had learned in the social context from which they came. They selected the words and expressions that best described their feelings and experiences. They learned to write those life stories or part of those life stories in Spanish and later English, adding a bilingual benefit to the process.

The participants revealed the way they reconstructed their identities in different moments, spaces and situations. Although they had faced down many challenges of abuse and violence, the personal toll was evident in diverse stories which portrayed loss of situational control; however, in the end (and sometimes with specialized help) they managed to overcome the hurt and pain. When students expressed themselves so candidly in writing, the teacher was better able to understand the reasons why sometimes they were bored and did not want to work in class. If teachers have a better understanding of what is behind students' life stories, we can see them as human beings with emotions, needs, feelings, expectations, facing challenging situations, situations 
with which we might be able to help them.

\section{References}

Altheide, D. (2002). Identity and the definition of the situation in a massmediated context. Arizona State University. Handbook of interview research p. 411-430). Thousand Oaks, CA: Sage.

Barkhuizen, G. (2011). Researcher Identity, Narrative Inquiry, and Language Teaching. Research BONNY NORTON AND MARGARET EARLY University of British Columbia Vancouver, British Columbia, Canada.

Belk, R. (1988). How do consumers express their identity? School of management working paper series, 2003.17.

Bruner, J. (1987). Life as narrative. Social Research, 54 (1), 11-32.

Connelly, F., \& Clandinin, D. J. (1990). Stories of experience and Narrative inquiry. Educational Researcher. American Educational Research Association 19, (5) 2-14 Published by: American Educational Research Association. Stable URL:http://www.jstor.org/ stable/1176100. Accessed: 06/09/2011 11:23.

Creswell, J. (2012). Educational Research. Planning, conducting and evaluating quantitative and qualitative research. FOURTH EDITION. University of Nebraska-Lincoln. Boston Columbus Indianapolis New York San Francisco Upper. p. 206.
Cumming, A. (2006). Goals for Academic Writing: ESL Students and Their Instructors.

Deng, F. M. (1995). War of Visions: Conflict of Identities in the Sudan. Washington, DC: Brookings.

Denzin, N.K. (1970, 1989). Interpretive Biography. Newbury Park, CA: Sage.

Dowling, S. J. (2011). Constructing Identity. Identity construction. Georgia State University.

Giddens, A. (1991). Modernity and SelfIdentity: Self and Society in the Late Modern Age, Stanford, CA: Stanford University Press, 1991, pp. 187-201.

Hardy, B. (1968). Towards a Conceptual History of Narrative. Matti Hyvärinen, University of Tampere.

Hogg \& Abrams. (1988). Identity theory and social identity theory. Washington State University.

Johnson \& Christensen. (2010). Educational Research: Quantitative, qualitative and mixed approaches. University of Nebraska - Lincoln Digital Commons: University of Nebraska - Lincoln.

Levinson, D. (1978). Theories of Identity and the Analysis of Face. University of Warwick institutional repository.

McAdams \& Brown, (2001). The Psychology of Life Stories. Northwestern University.

McAdams, D. (1993). The stories we live by: Personal myths and the making of the self. New York, NY: Guilford Press.

MacAdams, D. (1996). Personal narratives and the life story. New York. Oxford University Press. 
Neimeyer, R. A. (2000). Narrative disruptions in the construction of the self' in R. A.

Norton, B. (2000). Identity and language learning: Gender, ethnicity and educational change. London: Longman/ Pearson Education.

Norton, B. (2007, 2010, 2011). Identity, Language Learning, and Social Change. University of British Columbia, Canada.

Park, R. E., \& Burgess, E (1924). Assimilation. In introduction to the science of Sociology.Chicago: University of Chicago Press. p. 734-783.

Patton, M. (1990). Qualitative evaluation and research methods (pp. 169-186). BeverlyHills, CA: Sage. p.169.

Pavlenko, A. (2007). Autobiographic narratives as data in applied linguistics. Applied Linguistics, 28 (2), 163-188.

Pavlenko, A. \& A. Blackledge, A. (2004). Negotiation of identities in multilingual contexts. Multilingual Matters.

Clevedon, UK Polkinghorne, D. (2007). Analyzing Narratives and Story-Telling Matti Hyvärinen.

Ricoeur, P. (1991a). Life in quest of narrative.

In D. Woods (ed.), On Paul Ricoeur: Narrative and interpretation. London: Routledge, 20-33.

Riessman, C. (1993). Narrative Analysis. Newbury Park, CA: Sage (2008). Narrative Methods for Human Sciences Newbury Park, CA: Sage.

Robinson, H. (2007). Handbook of Self and Identity Edited by Mark R. Leary \& June
Price Tangney, Guilford Press, New York \& London.

Snow, D. A., \& Anderson L. (1987). Identity work among the homeless. The verbal construction and avowal of personal identities.

Squire, C. (2008). Experience-centred and culturally-oriented approaches to narrative. In M. Andrews, C. Squire \& M. Tamboukou (eds.), Doing narrative research. Los Angeles: SAGE. Publications, 41-63.

Squire, C. (2008). Memory and the Sense of Personal Identity, University of California, Santa Bárbara.

Street, B. (2003). What's "new" in New Literacy Studies? Critical Approaches to Literacy in theory and practice. Current issues in comparative education, 5(2), 7791.

Tajfel, H. (1978). Social identity theory and the organization. Blake E. Ashforth, Concordia University \& Fred Mael, Wayne State University.

Taylor, C. (1989). Sources of the self. The making of the modern identity. Cambridge, MA: Harvard University Press.

Thorborrow, J. (2005). Language and identity: The sociolinguistics of narrative. Studies in narrative. John Benjamins Publishing Company. Amsterdam/Philadelphia.

Tudor, I. (2001). The Dynamics of the Language Classroom. Cambridge Language. Teaching Library. Cambridge University Press. 
A Group of Eleventh Graders' Life Stories: Reconstructing Social Identity

Wenger, E. (1998-2000). Communities of practice: Learning, meaning, and identity. Cambridge, MA: Cambridge University Press. 


\section{Appendixes}

\section{Appendix 1: School Authorization}

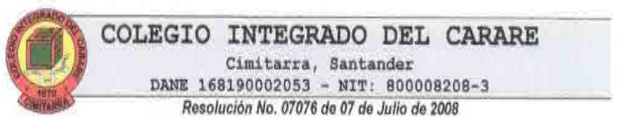

El rector del Colegio Integrado del Carare, autoriza a la docente losefina Penaloza Villamizar para la aplicación, ejecución y puesta en marcha del proyecto de investigacion: "Reconstrucción de la identidad personal" en la institución, como requisito de la Maestria en docencia de Idiomas de la Universidad Pedagógica y Tecnologica de Colombia, con sede en Tunja, Boyacá, aplicado en los grados 10 y 11 durante el tercero y cuarto periodo académico del año 2015.

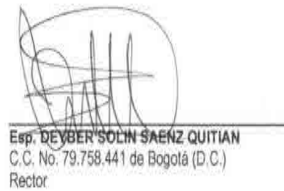

Appendix 2: Parents' consent form

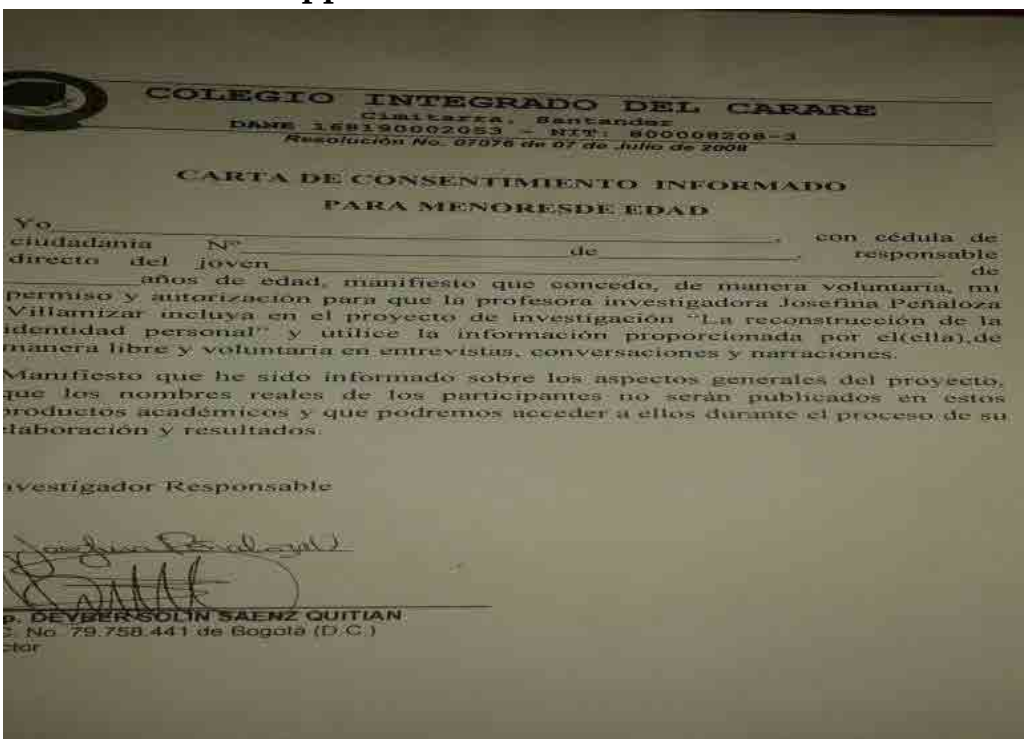




\section{Appendix 3: Sample of writing related tasks}

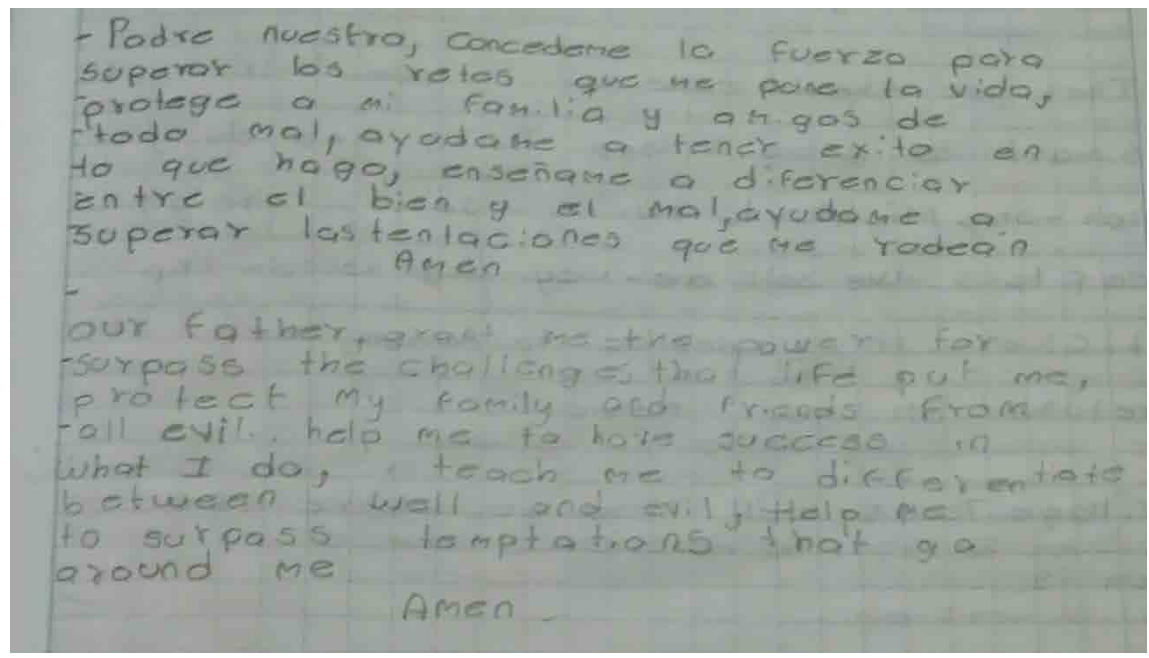

Appendix 4: Samples of Life Stories

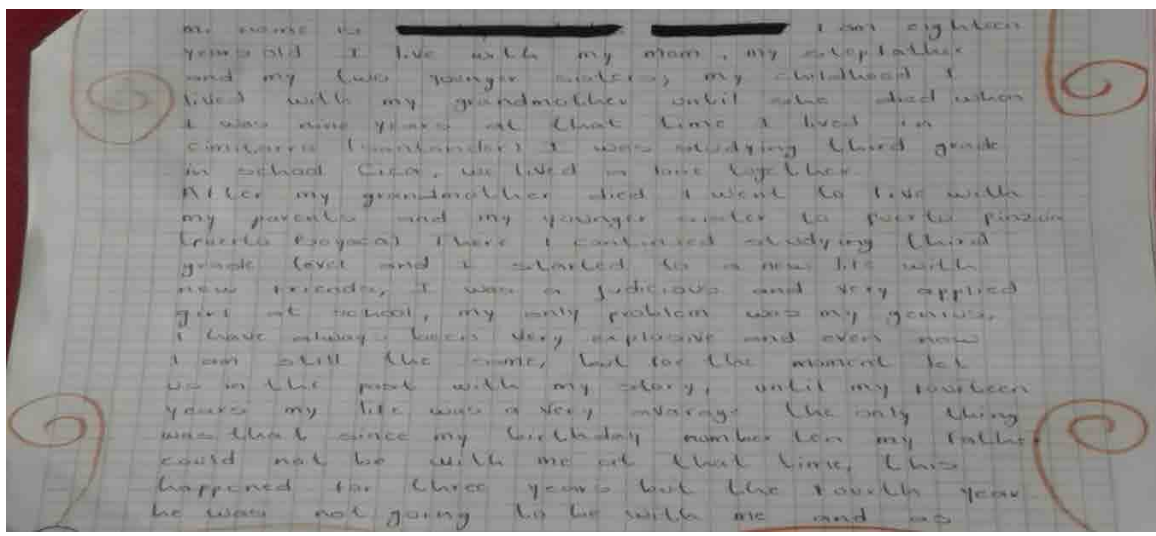




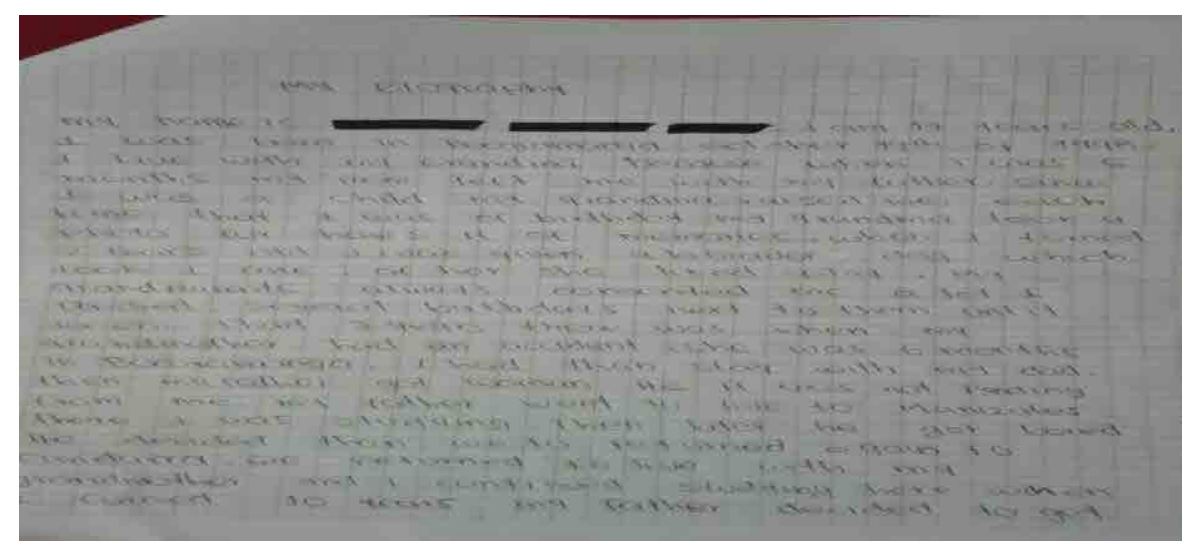

